\title{
Zadania recenzji i porządek w badaniach naukowych - polemika z Edwardem Haliżakiem
}

Profesor Edward Haliżak w odpowiedzi na opublikowaną przeze mnie recenzję tomu pod Jego redakcją ${ }^{1}$ nie po raz pierwszy wykazuje się niezrozumieniem podstawowych pojęć czy terminów, które funkcjonują w obiegu naukowym. W danym przypadku chodzi także o sens kryjących się za tymi terminami tekstów. Recenzja książki czy innej publikacji to przede wszystkim jej krytyczna ocena, a pierwszym obowiązkiem recenzenta jest sprawdzenie, czy treść utworu zgadza się z jego tytułem. Ocena ta obejmuje również stwierdzenie, czy utwór jest oryginalny oraz czy wnosi coś nowego do badań w danej dziedzinie. Recenzja nie jest natomiast (a przynajmniej nie musi być) kolejnym dziełem naukowym. Niżej podpisany wywiązał się jedynie z tej podstawowej funkcji. Z recenzentem można się nie zgadzać - i nierzadko się to zdarza - ale nie można się gniewać, że jest krytyczny, że nie dostrzega wielkości, że wskazuje na słabe strony ocenianego dzieła. Dojrzały badacz jak każdy twórca - musi mieć świadomość, że spotka się z krytyką. Recenzje uprzejme, grzecznościowe - a jest u nas takich niemało - niczego nie wnoszą do rozwoju nauki. Odpowiedź Profesora Haliżaka wskazuje na niezrozumienie istoty recenzji oraz brak odporności na krytykę.

Charakterystyczne, że Redaktor recenzowanego tomu ani słowem nie zareagował na zarzut błędnej definicji przedmiotu badania (polityki zagranicznej), gdzie tylko w jednym zdaniu znalazły się trzy poważne, dyskwalifikujące ją błędy. Właśnie tu jest sedno problemu. Nie wiedząc, o czym się pisze, nie można pisać dobrze. Wyjściowy błąd definicyjny obciąża całość i powinno być to oczywiste, bo przecież wynika z tego problem z konceptualizacją całości i doborem tekstów. To są sprawy elementarne i nie przesłoni ich najbardziej zadufana i przepełniona odniesieniami do teorii i metodologii odpowiedź na uwagi recenzenta. Podobnie ma się rzecz z gromko

1 Badanie polityki zagranicznej państwa, red. E. Haliżak, Rambler, Warszawa 2018. 
przywoływanymi przez autora przypisami do biurokratycznego formatowania badań polityki zagranicznej. Recenzowane studia należą jednak przede wszystkim do nauk o polityce, co wynika chociażby z samej nazwy przedmiotu badań - polityki zagranicznej.

Od kosmologii Arystotelesa wiemy, że spójność i atrakcyjna forma prezentacji teorii nie sprawiają jeszcze, że jest ona prawdziwa, to znaczy stosunkowo wiernie odzwierciedla rzeczywistość lub przynajmniej przybliża do jej poznania. Podobnie samo opanowanie naukowego żargonu (w tym wszystkich izmów) nie oznacza automatycznie, że pisze się rzeczy mądre. Dlatego właśnie w naszych naukach społecznych odróżniamy teksty naukowe od naukawych. Warto więc zacząć od zdrowego rozsądku, jako bazy naukowego poznania (szerzej pisał o tym m.in. ks. prof. Mieczysław Albert Krąpiec). Jeśli brakuje tego w naszym badaniu, pojawia się frazeologiczna pretensjonalność, która nie wnosi do poznania niczego wartościowego, i tak właśnie jest w przypadku wywodów Profesora Haliżaka. Redaktor tomu nie rozumie, że teoretyzowanie o polityce zagranicznej nie powinno być procedurą autoteliczną, że teorie nie mogą obsługiwać samych siebie, a trywialność przynoszonych przez część z nich efektów poznawczych każe utrzymywać wobec nich zdroworozsądkowy dystans.

Profesorowi Haliżakowi nie spodobała się dobrze znana w środowisku nauk społecznych metafora $\mathrm{z}$ ornitologiem (niektórzy pamiętają nawet nazwisko uczonego i sytuację, w której powstała). Skoro nie przypadła ona Redaktorowi do gustu, posłużę się inną: na podstawie kilku podręczników do nauki pływania nie można napisać kolejnego wartościowego, jeśli nie weszło się uprzednio do wody i nie próbowało pływać. Znajomości tej sztuki należałoby oczekiwać przede wszystkim od Redaktora tomu (autorzy wielu zawartych tam artykułów z pewnością ją posiedli), zwłaszcza gdy zgodnie ze swą znaną manierą poucza innych. Nawet powoływanie się na największe autorytety w nauce pływania nie czyni nikogo instruktorem, jeśli sam nie był nigdy w wodzie, a tak właśnie jest w przypadku recenzowanej publikacji pod redakcją Profesora Haliżaka. To właśnie nieznajomość przedmiotu badań nie pozwoliła $\mathrm{Mu}$ właściwie ocenić pożytku z usilnego, lecz jałowego poznawczo teoretyzowania na tym gruncie.

Negatywnie recenzowane próby Profesora Haliżaka w Jego pierwotnym obszarze badawczym (międzynarodowych stosunkach gospodarczych) skłoniły Go do wypłynięcia na inne wody. Liczne dobre przykłady takich decyzji pokazują, że nie ma w tym niczego niewłaściwego, tylko aby żeglować z powodzeniem, warto zacząć od mniejszych, bardziej bezpiecznych 
akwenów; warto wpierw dobrze poznać nowy obszar badawczy. Potrzeba tu zapewne szczypty pokory i naukowej skromności... Droga na skróty często wiedzie na manowce. W pracy badawczej dochodzi do tego, gdy bez odpowiedniego przygotowania zabieramy się od razu za rzeczy wielkie. Ucieczka we wzniosłe teoretyzowanie nie przesłoni poznawczej jałowości takich procedur i nikłych rezultatów badawczych. W pracy naukowej nie należy się kierować hasłem „Damy radę!”, które rozpleniło się w naszym życiu publicznym. Jak w każdej dziedzinie poważny cel wymaga poważnego podejścia i rzetelnej pracy.

To prawda, że nie mogę się równać statusem naukowym z Profesorem Haliżakiem. Daruję sobie złośliwości pod adresem rekordów w czasie sprawowanych przez Niego funkcji, bo niektóre przerywane były w niezbyt chwalebny sposób. Pod względem formalnego statusu żaden polski naukowiec uprawiający naszą dyscyplinę nie może się równać z Profesorem Haliżakiem - nie mam problemu, by to uznać. Osobie, która osiągnęła taką pozycję, łatwo zebrać zespół do wspólnego przedsięwzięcia. Na inicjatora i szefa takiego projektu spada jednak obowiązek wykazania się należytą kompetencją w obranym przedmiocie badań i odpowiedzialność za jego końcowe powodzenie. Jeśli tego zabraknie - jak w przypadku recenzowanej pracy - wysiłek zespołu w dużej mierze idzie na marne. Znakomita większość tekstów zamieszczonych w tym tomie $\mathrm{z}$ powodzeniem broniłaby się indywidualnie na łamach periodyków czy w pracach zbiorowych na inne tematy. Uważam, że ich autorom należą się od Redaktora naukowego tego tomu przeprosiny, że namówił ich na wspólne przedsięwzięcie, do którego sam nie był jeszcze przygotowany. W pracy zbiorowej suwerenność badawcza autorów ograniczona jest wyjściowymi założeniami określanymi przez redaktora naukowego oraz jego zdolnością do krytycznego spojrzenia na wnoszone przez nich teksty. Tymczasem zamiast spójnego tomu na sygnalizowany w tytule temat czytelnik otrzymuje publikację eklektyczną. Płynie z tego nauka, że oddając teksty do pracy zbiorowej, powinno się brać pod uwagę ryzyko związane z osobą jej redaktora. W tym przypadku przeprosiny z jego strony należą się także czytelnikowi, ponieważ tytułowa zapowiedź nie została zrealizowana i został on wprowadzony w błąd.

Dość osobliwie brzmi w odpowiedzi Profesora Haliżaka przypisanie mi odpowiedzialności czy współodpowiedzialności za niską pozycję Uniwersytetu Warszawskiego w światowych rankingach. Sam nigdy bym sobie takiej wagi nie przypisał. Mówiąc jednak poważnie, miejsce uniwersytetów w większym stopniu zależy od jakości prowadzonych przez nie badań niż od recenzji tych 
badań. Te drugie dobrze służą pierwszym, jeśli autorzy recenzowanych prac wykazują się dojrzałością i wyciągają z krytyki pożytek. Reakcja Edwarda Haliżaka na moją recenzję pokazuje, że nie jest to ten przypadek. Na szczęście podobnie jak ja nie ma On większego wpływu na miejsce Uniwersytetu Warszawskiego w rankingach.

Roman Kuźniar 